\title{
Viskoelastické metody jako standard monitorováni hemostázy? - editorial
}

\author{
Roman Hájek \\ Kardiochirurgická klinika LF UP a FN Olomouc \\ Komentář k | Editorial on \\ Durila M. Rotačná tromboelastometria v terapii život ohrozujúceho krvácania. Vnitř Lék 2018; \\ 64(4): 380-383.
}

Viskoelastické metody, čtvrtstoletí po svém znovuobjevení (byly poprvé použity již roku 1948) nejprve anesteziology v relativním ústraní kardiochirurgických a transplantačních center a zhruba $s$ desetiletým zpožděním i komunitou intenzivistů včetně autorit formulujících doporučení k léčbě život ohrožujícího krvácení [1], prodělávají vítězné tažení a zdá se dnes téměř ignorantstvím je nepoužívat prii relativní dostupnosti v podmínkách naší země. Je pozoruhodné, jak dlouho trvalo, než se obliba "bedside "či „point-of-care" vyšetřovacích metod přenesla i do oblasti hemostázy a jak dlouho byly (a někdy stále ještě jsou) tyto metody vnímány s despektem komunitou hematologů, přestože z tohoto prostředí vzešly. Dnes jsou globální testy hemostázy na výsluní a objevuji se i v doporučení sledování vyloženě hematologických onemocnění, např. hemofilie [2]. Přes upř́mně míněné vědecké srovnávání predností a nevýhod obou dostupných metod - tromboelastografie (TEG) a rotační tromboelastometrie (ROTEM, připomeňme, že tento novotvar vznikl z původního ROTEG jen pro to, že zkratka TEG je chráněným názvem původního výrobce), které má jistě dle preference a zkušeností s užitím obou systémů své zapřisáhlé zastánce a odpůrce, nemá tato diskuse z praktického klinického hlediska zásadní opodstatnění, fyzikální princip obou systémů je prakticky identický a v literatuře dobře popsaný [3]. Technické řešení obou analyzátorů dostupných na českém trhu je ovšem rozdílné a tady je jistě mnoho prostoru na individuální preference, jako je tomu i u jiných prístrojů. Podstatnější je, že $v$ zahraničí jsou již dostupné přístroje nové generace pracující s použitím jednoduše plněné multifunkční cartridge pro širší paletu vyšetření, což podstatně zjednodušuje práci uživatele, odpadá např̀ pipetování vzorku krve, jež může být zdrojem značné nepřesnosti a artefaktů prí analýze. Pro úplnost je třeba uvést, že existují i jiné viskoelastické testy pracující na jiném principu než TEG/ROTEM, např. poměrně starý systém Sonoclot pracující se změnami akustické impedance ultrasonografického signálu při tvorbě koagula, tento systém je v Evropě raritně užívaným. Práce, k níž je napsán tento komentáŕ, nezmiňuje některé významné limitace viskoelastických metod. Správně je zdůrazněna přednost vyšetření plné krve. Je třeba mít na paměti, že jde však stále o metodu „in vitro ", která v žádném prípadě nepostihuje všechny složky hemostázy „in vivo“, především významnou složku endotel-celulární interakce. Existuje více (ne úplně vzácných) onemocnění, která nelze pomocí TEG/ROTEM zachytit, např. von Willebrandtovu chorobu. Rovněž funkce destiček je zachycena jen "globálně“a nelze bez dalších modifikací (např. tzv. platelet mapping) diferencovat vliv dnes tolik rozšířené protidestičkové terapie. Mimo zmíněných preanalytických úskalí vyžadujících určité zaškolení operátora a dodržení času od odběru do zpracování vzorku (turn-around) hrají roli další prí́datné faktory - aktuální teplota, hladina ionizovaného kalcia, při níž se vůbec koagulum začne formovat, stupeň hemodiluce, správná manipulace $s$ testovacími nádobkami obsahujícími heparinázu atd. $\mathrm{V}$ některých studiích byla zmiňována nízká reprodukovatelnost vyšetření jistě ovlivněná zkušeností operátora. Opakovaně citovanou námitkou je chybějící srovnání se „zlatým standardem", který Ize v prípadě globálních testů opravdu obtížně definovat - může jím být snad jednoduchý, ale obtižně interpretovatelný a reprodukovatelný test krvácivosti dle Duke či lvy? Největši předností je bezesporu rychlost získání výsledku, což může být v podmínkách léčby život ohrožujícího krvácení faktor rozhodujíí. Přesto je třeba data z klinických studií interpretovat $\mathrm{s}$ jistou opatrností. Recentní metaanalýzy $[4,5]$ přinesly závěry, že algoritmy terapie řízené TEG/ROTEM (10 studií, 832 pacientů) vedou $k$ redukci transfuzí erytrocytů [RR $(95 \% \mathrm{Cl}) 0,86]$, čerstvě zmrazené plazmy $(\mathrm{RR} 0,57)$ a trombocytů (RR 0,73 \%), nikoli však k redukci chirurgických reoperací pro krvácení. Byla rovněž prokázána redukce celkové mortality (8 studií, 717 pacientů) 3,9 vs 7,4 \% [RR $(95 \% \mathrm{Cl}) 0,52]$. Co je podstatné a nikoli neobvyklé v podobných studiích - do metaanalýzy mohla být zahrnuta data pouze 15 ze 46 vybraných studií z důvodů úplnosti dat a kvality metody, z toho 9 studií bylo z oblasti kardiochirurgie. Samozřejmě jde jen o nízké počty pacientů. Z pohledu lékaře pracujícího posledních 16 let na kardiochirurgickém pracovišti musím konstatovat, že je v praxi 
velmi obtížné striktně se řídit nějakým rigidním diagnosticko-terapeutickým algoritmem v situaci pokračujícího významného krvácení po velkém operačním výkonu, často mnohahodinovém, kdy má chirurg dobré důvody váhat s reoperací, za niž je výhradně odpovědný. V̌zádné publikované studii nebyla vyhodnocena negativní prediktivní hodnota TEG/ROTEM u tzv. krvácení z chirurgických přícin, přestože se logikou "selského rozumu“ samož̌ejmě nabízí (normální TEG = chirurgické krvácení?). Naopak v řadě situací, známých nejen z chirurgie a traumatologie, ale i z vnitřního lékařství, např. akutní varikózní krvácení, je někdy nutno bez ohledu na guidelines a výsledky bedside či laboratorních metod aktivovat masivní transfuzní protokol vycházející ze zkušeností urgentní a válečné medicíny, či dokonce bez většího váhání sáhnout časně po „off label“ rescue postupu a podat aktivovaný faktor VII samozřejmě při splnění bazálních kritérií (adekvátní teplota, $\mathrm{pH}$, hematokrit, hladina fibrinogenu a trombocytů). Tyto "chirurgické" zkušenosti jsou jistě alespoň částečně extrapolovatelné i do prostředí interní medicíny. V neposlední řadě nezapomínejme, že pohled hematologa, který se zdá někdy intenzivistům až př́liš analytický a poněkud zdlouhavý, je bezesporu pohledem hlubším a opírajícím se o širší souvislosti stále tajuplného a obtížně uchopitelného procesu, kterým hemostázaje.Je potěšující,žezájem hematologůo viskoelastické metody roste, a tím i naše celková úroveň vědomostí o jejich možnostech i limitech. Každopádně viskoelastické metody výrazně doplňují možnosti intenzivistů (a nejen nich) a budou $v$ diagnostice a terapii poruch hemostázy nepochybně brzy etablovány i na pracovištích interních oborů a vědecký i technologický pokrok z nich časem učiní efektivnější nástroj v léčbě jednoho z mnoha obávaných kritických problémů medicíny.

\section{Literatura}

1. Rossaint R, Bouillon B, Cerny V et al. The European guidelines on management of major bleeding and coagulopathy, fourth edition. Crit Care 2016; 20: 100. Dostupné z DOI: <http://dx.doi.org/10.1186/ s13054-016-1265-x>.

2. Chitlur M, Rivard GE, Lillicrap D et al. Recommendations for performing thromboelastography/thromboelastometry in hemophilia: communication from the SSC of the ISTH. J Thromb Haemost 2014; 12(1): 103-106. Dostupné z DOI: <http://dx.doi.org/10.1111/jth.12458>.

3. Shen $L$, Tabaie S, Ivascu N. Viscoelastic testing inside and blond the operating room. J Thorac Dis 2017; 9(Suppl 4): S299-S308. Dostupné z DOI: <http://dx.doi.org/10.21037/jtd.2017.03.85>.

4. Wikkelso A, Wettersley J, Moller AM et al. Thromboelastography (TEG) or rotational thromboelastometry (ROTEM) to monitor haemostatic treatment in bleeding patiens: a systematic review with meta-analysis and trial sequential analysis. Anaesthesia 2017; 72(4): 519531. Dostupné z DOI: <http://dx.doi.org/10.1111/anae.13765>.

5. Fahrendorff M, Olivieri RS, Johansson PI. The use of viscoelastic haemostatic assays in goal-directing treatment with allogeneic blood products - A systematic review and meta-analysis. Scand J Trauma Resusc Emerg Med 2017; 25(1): 39. Dostupné z DOI: <http://dx.doi. org/10.1186/s13049-017-0378-9>.

\section{MUDr. Roman Hájek, Ph.D.} $\triangle$ roman.hajek@fnol.cz

Kardiochirurgická klinika LF UP a FN Olomouc www.fnol.cz

Doručeno do redakce 25. 11. 2017 